\title{
Why do Adolescents Seek Career Counseling? A Predictor Study of Brazilian Students
}

\author{
Rodolfo Augusto Matteo Ambiel ${ }^{*} 1$ \\ Orcid.org/0000-0002-3921-8547 \\ Gustavo Henrique Martins ${ }^{1}$ \\ Orcid.org/0000-0002-5125-2553 \\ Débora Noemí Hernández ${ }^{1}$ \\ Orcid.org/0000-0003-1689-3272
}

${ }^{1}$ Universidade São Francisco, Campinas, SP, Brasil

\begin{abstract}
Career counselors who routinely practice their profession identify the motives that lead their clients to be more indecisive or inclined to seek their services, yet still with little scientific support. That being the case, the present study's aim was to examine the extent to which variables such as personality, career adaptability, self-efficacy and career exploration explain career indecision and the intention to seek Career Counseling. The study enjoyed the participation of 237 sophomores, juniors and seniors from a public high school, and the majority of the students were female. We performed two Multiple Linear Regression Analyses using the forward method, employing Career Indecision and Seeking Career Counseling as the outcome variables. The results indicated that Neuroticism and Self-Exploration positively predicted the cases; Environmental Exploration negatively predicted Career Indecision; and Self-Assessment negatively predicted seeking career counseling. We thus conclude that adolescents seek career counseling either because they feel emotionally vulnerable or because they are seeking selfknowledge, or even because they do not believe in their career-related self-knowledge.
\end{abstract}

Keywords: Career counseling, high school students, psychological assessment.

\section{Por que os Adolescentes Buscam Fazer Orientação Profissional? Um Estudo Preditivo com Estudantes Brasileiros}

\section{Resumo}

Orientadores profissionais que atuam na prática rotineiramente identificam motivos que fazem seus clientes serem mais indecisos ou propensos a buscarem seus serviços, contudo ainda com pouco amparo científico. Sendo assim, o objetivo deste artigo foi verificar o quanto variáveis como personalidade, adaptabilidade de carreira, autoeficácia e exploração vocacional explicam a indecisão vocacional e a intenção de busca por orientação profissional. Participaram deste estudo 237 estudantes dos três anos do ensino médio de uma escola pública, sendo a maior parte do sexo feminino. Foram realizadas duas

* Mailing address: Rua Waldemar César da Silveira, 105, Vila Cura D’Ars, Campinas, SP, Brazil, 13045-510. Phone: (19) 3779-3300. E-mail: rodolfoambiel@usf.edu.br

Support: Conselho Nacional de Desenvolvimento (CNPq). 
Análises de Regressão Linear Múltipla, com método forward, sendo usadas como variáveis desfecho a Indecisão e a busca por Orientação Profissional. Os resultados indicaram que os casos foram preditos positivamente por Neuroticismo e Exploração de Si; a Exploração do Ambiente predisse negativamente a Indecisão; a Autoavaliação predisse negativamente a busca por orientação profissional. Conclui-se que os adolescentes buscam orientação profissional por se sentirem vulneráveis emocionalmente, por estarem buscando se conhecer, ou por não acreditarem no seu autoconhecimento profissional.

Palavras-chave: Orientação vocacional, estudantes de ensino médio, avaliação psicológica.

\section{Por que los Adolescents Buscan Orientación Prefesional? Un Estudio Predictivo com Estudiantes Brasileños}

\section{Resumen}

Orientadores profesionales que actúan en esta práctica habitualmente identifican motivos que hacen que sus clientes sean más indecisos o propensos a buscar sus servicios, pero sin mucho amparo científico. De esta forma, el objetivo de este artículo fue verificar cual es la influencia cuantitativa de las variables de personalidad, adaptabilidad de carrera, autoeficacia y exploración vocacional en la predicción de la indecisión vocacional y la intención de buscar por orientación profesional. En este estudio participaron 237 estudiantes de los tres años de secundaria de una escuela pública, siendo la mayoría del sexo femenino. Fueron realizadas dos Analices de Regresión Linear Múltiple con el método forward, con las variables desencadenadas la Indecisión y la busca por Orientación Profesional. Los resultados indican que ambos casos fueron previstos positivamente por el Neuroticismo y la Exploración de Sí. Además, Exploración del Ambiente predice negativamente la Indecisión, y de la misma manera la Auto-evaluación predice negativamente la busca por orientación profesional. Concluyendo que los adolescentes buscan la orientación profesional cuando se sienten emocionalmente vulnerables, cuando desean buscar conocerse o por no creer en su propio autoconocimiento profesional.

Palabras clave: Orientación vocacional, estudiantes de secundaria, evaluación psicológica.

With a tendency for being stressful and upsetting for teenagers due to all the typical physical and social changes, adolescence is also the moment of development that entails adolescents' first career choices related to their future profession (Reis et al., 2015). In order to help adolescents accomplish such a task, career counseling services emerge as a possible alternative. In Brazil, the most commonly used term for referring to such services continues to be Orientação Profissional (Ribeiro, 2011; literally translated as "Professional Orientation," yet much more commonly referred to as Career Counseling in English. For this reason, $\mathrm{CC}$ will be the term used to refer to such guidance in this article). CC was defined by Savickas (1999) as a process whose principal objective is to counsel people regarding their careers so as to provide them with both a better understanding of the characteristics of professions and greater self-knowledge, thus fostering previously unperceived potentials.

In 2004, the Organization for Economic Cooperation and Development (OECD) developed a guidebook known as Career Guidance: A Handbook for Policy Makers, whose chief aim was to help policymakers develop efficient public policies for promoting career counseling/ guidance. In the Portuguese-language version of the handbook (translated into English here), the OECD defines career guidance as follows:

A group of activities that enable individuals of all ages, at any moment in their lives, to identify their abilities, skills and interests; make important decisions at the scholastic, training and career levels; and manage their individual life projects in terms of their studies, work and other contexts in which such abilities and skills are acquired or em- 
ployed. Counseling is offered in various contexts: education, training and employment, at both a community and a private level. (OECD, 2004, p. 84)

It is also noteworthy that CC plays an important role in society because individuals that make the right choices become more satisfied, in both the personal and professional spheres, practicing their professions in a more efficient and productive manner for society (Carvalho, 1995; Ribeiro \& Uvaldo, 2007). Furthermore, because it addresses issues related to individual wellbeing, the CC process is an "important tool for promoting health" (Santos, Luna \& Bardagi, 2014, p. 277). In addition, Carvalho (1995) stated that young people who seek CC are seeking help with the choices they have to make for their professional future.

Several authors have shown interest in understanding the reasons for which people seek CC. For example, Ribeiro (2003) conducted a survey of 252 juniors and seniors from various suburban São Paulo public high schools, who were assessed by way of a semi-open interview. The author observed that the students' chief complaint during $\mathrm{CC}$ was the lack of vocational information and of research sources related to their socio-occupational situation. In the same year, Bardagi, Lassance, and Paradiso (2003) published a survey of a sample of 391 students who were half way through their studies at a federal university and who answered a questionnaire that had been developed exclusively for the study, consisting of semi-structured questions. The authors discovered that the participants' main reason for participating in a $\mathrm{CC}$ process was their need for more information regarding careers, courses of study, the labor market and vocational fields, a fact that was interpreted as a potential career-search shortcoming when choosing a course of study. Lastly, Semensato et al. (2009) performed a qualitative survey of 20 high school seniors. The study's results indicated the existence of three principal motives for such students to seek CC: doubt, indecision and lack of information. That being the case, the authors concluded that people seek $\mathrm{CC}$ as a form of assistance for deciding about their future professions.

Although CC can be conducted in various manners and for different types of groups, counseling teenagers seeking help to select the best university course for themselves undoubtedly is still the most well established guidance practice (Bonadiman, Scaff, Bardagi, \& Luna, 2016; Melo-Silva, Lassance, \& Soares, 2004). In Brazil, the term "CC" came to be traditionally associated with a process that aims to help young people to reflect more effectively in times of indecision in relation to their career choices (Silva, 2010). As aforementioned, indecision has been proving to be an important issue to be addressed in the CC process; it has already been identified as the second most studied construct in vocational psychology, only lagging behind professional interests (Kelly \& Lee, 2002). Career indecision is defined by the difficulties people come across when they need to make career-related decisions (Saka, Gati, \& Kelly, 2008).

Several studies related to teenage indecision in Brazil indicate the existence of significant positive correlations between indecision and anxiety and depression. Furthermore, it has also been observed that low indecision scores are associated with adolescents who have already made their career choices. On the other hand, high scores were observed in only children and middle children in comparison with the others (Hutz \& Bardagi, 2006). Another study determined that goal instability and combined parental responsiveness together explain $12.7 \%$ of career indecision, with goal instability being a mediating variable for this correlation (Magalhães, Alvarenga, \& Teixeira, 2012). A further study revealed indecisiveness to be slightly negatively correlated with optimism (Campos \& Noronha, 2015). Lastly, it was observed that individuals who exhibited greater indecisiveness obtained higher scores in terms of professional choice self-efficacy and selfexploration (Ambiel \& Hernández, 2016).

Frequently, the principal focus in a CC process is to help clients identify their personal traits 
so as to minimize their indecisiveness (Campos \& Noronha, 2015; Noronha \& Ambiel, 2008). Hence, a possible behavioral strategy for dealing with such a difficulty is that of career exploration (Cunha \& Faria, 2009) because indecisiveness can be considered a result of ineffective exploration (Faria, Taveira, \& Saavedra, 2008). Career exploration is most common in adolescence and early adulthood, it being defined as behaviors focused on problem solving, discoveries, experimentation, and knowledge of oneself and of the world of work, which is essential for making career choices (Brown \& Lent, 2005; Joordan, 1963).

In addition to career indecision and exploration, various researchers have also displayed interest in studying individuals' self-regulatory functioning and how it is involved in career decision-making processes. In this respect, two constructs have been widely studied in the Brazilian and international literature: self-efficacy and career adaptability. Although they belong to different theories, namely social cognitive career theory (Lent, Brown, \& Hackett, 1994) and career construction theory (Savickas, 2005), respectively, they both mediate the relationships between dispositions and behaviors. They are thus considered self-regulatory processes (Lent et al., 1994; Rossier, 2015). By definition, selfefficacy is one's belief in one's ability to plan and execute courses of action that are necessary to achieve certain outcomes (Bandura, 1997). Meanwhile, career adaptability is defined as a "psychosocial construct that indicates an individual's preparedness and resources for dealing with present and future career-development tasks and with career changes and personal traumas" (Savickas, 2005, p. 51). A survey conducted by Guan et al. (2016) of 731 Chinese university students discovered a significant positive correlation between career decisionmaking self-efficacy and career adaptability.

Some counselors also seek to comprehend the correlations between psychological and dispositional factors and vocational behavior (i.e. the manner in which individuals' psychological characteristics relate to career-associated constructs). Among the psychological constructs that are most researched within this context, one encounters personality, which is comprehended and researched worldwide by means of the Big Five model. Along these lines, various studies in Brazil have sought to associate personality with other vocational psychology (career counseling) constructs, such as career interests (Bueno, Lemos, \& Tomé, 2004; Noronha, Mansão, \& Nunes, 2012; Primi et al., 2002; Valentini, Teodoro, \& Balbinotti, 2009); career self-efficacy, career planning, career decision making and career exploration (Ourique \& Teixeira, 2012); career decision-making self-efficacy (Ambiel \& Noronha, 2016); career adaptability (Bardagi \& Albanaes, 2015; Teixeira, Bardagi, Lassance, Magalhães, \& Duarte, 2012); and protean careers (Borges \& Andrade, 2014), among others.

As has been shown up to this point, many factors are involved in vocational behavior. Nonetheless, which of them can actually be associated with an individual's desire to seek career counseling? Aiming at answering this question, several studies have reported motives that are external to the individual (Bardagi et al., 2003; Ribeiro, 2003; Semensato et al., 2009). We found no studies concerning the influence of individuals' internal motives for their intention to seek career-counseling services. Accordingly, the present study's aim was to investigate the manner in which variables such as personality, adaptability, self-efficacy and career exploration explain career indecision and the intention to seek career counseling. Once the psychological factors involved in such processes (career indecision and seeking career counseling) are known, counselors can also work from a preventive standpoint in order to offer support for such needs.

Based on a survey we conducted of the scientific literature on the subject, the present study's hypotheses are as follows: H1) indecision is positively explained by openness and neuroticism and negatively explained by conscientiousness and self-efficacy (Ambiel \& Hernández, 2016; Campos \& Noronha, 2015; Hutz \& Bardagi, 2006; Ourique \& Teixeira, 2012); and H2) exploration of both the self and the environment is a construct that positively predicts career in- 
decision and seeking CC (Ambiel \& Hernández, 2016; Bardagi et al., 2003; Faria et al., 2008; Ribeiro, 2003; Semensato et al., 2009).

\section{Method}

\section{Participants}

A convenience sample consisting of 237 students from a public high school in the interior of the state of São Paulo was selected for this study. Their mean age was 16.31 years $(S D$ $=0.98)$, with ages ranging between 14 and 19 years, and the majority of the students were female (53.2\%). Two participants did not provide such information. $39.7 \%$ of the students were high school sophomores; $28.7 \%$, juniors; and $30.8 \%$, seniors. Three participants did not report their high school year.

\section{Instruments}

Personal information questionnaire. This instrument consisted of questions related to age, sex, and high school year, as well as a closedended question concerning the participant's intention to seek CC. Before this question was asked, respondents were given a brief explanation of the Career Counseling process, after which they were asked to complete the statement "Considering the way I currently think about my future..." by marking one of the following three options: (a) I would not seek career counseling since I'm already sure of what I want to do in the future; (b) Although I already know what I want to do in the future, I would still seek career counseling because it could help me be sure I'm on the right track; or (c) I would seek career counseling since I have no idea what I will do next year. For analysis purposes, the data was tabulated as 1 (option a), 2 (option b) and 3 (option $\mathrm{c}$ ), with 1 signifying the least intention on the part of the student to seek CC and 3 signifying the most intention.

Mini-Markers for Personality Assessment (Hauck, Machado, Teixeira, \& Bandeira, 2012; Hauck, Teixeira, Machado, \& Bandeira, 2012). Assesses personality by means of adjectives based on the Big Five personality model. It consists of 25 markers (e.g., Communicative) that are evenly distributed among five dimensions: extroversion, socialization, conscientiousness, neuroticism and openness. Answer options are arranged according to a five-point Likert scale ranging from (1) "totally disagree" to (5) "totally agree." The instrument exhibits satisfactory accuracy, with Cronbach's alpha varying between 0.61 (openness) and 0.83 (extroversion). The instrument's good psychometric properties for this population were confirmed in a study conducted by Hauck, Teixeira, et al. (2012) with samples of high school students. In the present study, the following Cronbach's alphas were obtained: 0.71 (socialization), 0.70 (conscientiousness), 0.66 (neuroticism), 0.54 (openness) and 0.46 (extroversion).

Career Adapt-Abilities Scale (CAAS; Teixeira et al., 2012). This scale assesses career adaptability factors. Participants rate the extent to which they believe they have developed each skill according to a Likert scale ranging from "very little" (1) to "fully" (5). The scale consists of 24 items, which by way of confirmatory factor analysis were grouped into four factors (as hypothesized): concern, control, curiosity and confidence. These factors obtained satisfactory accuracy values, with Cronbach's alphas varying from 0.76 (control) to 0.82 (confidence) and an overall score of 0.91 . A survey of adolescents confirmed the CAAS's psychometric properties for this population, exhibiting Cronbach's alphas ranging between 0.81 (control and curiosity) and 0.86 (confidence; Ambiel, Carvalho, Martins, \& Tofoli, 2016).

Professional Choice Self-Efficacy Scale (EAE-EP, initials in Portuguese; Ambiel \& Noronha, 2014). This scale requires participants to answer the question "How strongly do you believe in your ability to ..." according to a fourpoint Likert scale, where 1 represents "I hardly believe" and 4 represents "I strongly believe." It is made up of 48 items distributed among four factors: self-assessment (participants' beliefs concerning their ability to describe themselves and choose a career); career data collection (participants' opinions as to their ability to seek out career information while making use of various strategies); practical career information search- 
ing (participants' beliefs regarding their ability to acquire career information through interpersonal relationships); and future planning (participants' beliefs concerning their ability to contemplate issues related to their future education, career or financial matters). The instrument's alpha values ranged between 0.79 (future planning) and 0.88 (self-evaluation), with 0.94 for the full scale. In the present study, all of the alpha values were greater than 0.77 .

Career Exploration Scale (EEV, initials in Portuguese; Teixeira, Bardagi, \& Hutz, 2007; Teixeira \& Dias, 2011) assesses the exploratory behavior of high school students by way of two factors: self-exploration (the pursuit of greater self-knowledge) and environmental exploration (the pursuit of educational and career alternatives). The scale consists of 24 items evenly distributed among the factors and assessed according to a five-point Likert scale varying between "rarely or never" (1) and "very often or always" (5). The scale's internal consistency was considered satisfactory, with Cronbach's alpha ranging between 0.81 for Environmental Exploration and 0.83 for Self-Exploration. Similarly, in the present study the Cronbach's alphas we obtained were 0.85 (environmental exploration) and 0.82 (self-exploration).

Career Indecision Scale (EIV, initials in Portuguese; Teixeira \& Magalhães, 2001) seeks to measure high school students' level of career indecisiveness via a one-dimensional model. The scale consists of 30 items that are assessed according to a five-point Likert scale ranging from "the statement is completely false with respect to me" (1) to "the statement is completely true with respect to me" (5). The scale's accuracy was considered satisfactory, with a Cronbach's alpha of 0.92 (career indecision). In the present study, the scale's accuracy was maintained, with a Cronbach's alpha of 0.88 .

\section{Procedures}

Ethical procedures. We first contacted the high school's coordinator. After explaining the project to her, she authorized us to conduct the survey. The project was then submitted to and approved by the São Francisco University Re- search Ethics Committee (ruling no. 810,064). Subsequent to the ruling, we again contacted the high school in order to deliver the informed consent forms, which were subsequently forwarded to the participants' parents, informing them that the only students who would be able to participate in the survey were those whose parents/guardians consented to it. The coordinator herself was responsible for receiving the completed, signed forms; and, as soon as most of the students (around $90 \%$ of those who had been invited) had delivered them, she informed the researchers, who scheduled the date for administering the questionnaires. In turn, approximately one month after data collection, one of the authors returned to the school and gave a talk on career choices to all of the students from the participating classes, regardless of whether or not they had participated in the study.

Data collection. Data collection was conducted collectively in the classrooms during class hours, with approximately 40 students in each classroom. Collection lasted approximately 40 minutes. The instruments were administered by two psychologists and two undergraduate scholarship psychology students.

Data analysis. The data was tabulated and analyzed in SPSS spreadsheets. Subsequently, we performed descriptive analyses of the sample and of the variables employed for this study. Using Cronbach's alpha, the factors' internal consistency was also assessed. With respect to the alpha values, we referred to the recommendations of George and Mallery (2002), who contend that values below 0.50 are considered unacceptable; between 0.50 and 0.59 , poor; between 0.60 and 0.69 , questionable; between 0.70 and 0.79 , acceptable; between 0.80 and 0.89 , good; and above 0.90 , excellent. Furthermore, we made comparisons between sophomores, juniors and seniors with respect to the effect sizes of the means of the variables employed. In order to interpret the results, we referred to the considerations made by Cohen (1988), whereby values of $d=0.2$ are considered small effects; $d=0.5$, average; and $d=0.8$, large.

Subsequent to analyzing the instruments' internal consistency, we conducted two Mul- 
tiple Linear Regression Analyses, employing the forward method. All of the prerequisites for conducting regression analysis were satisfied, indicating the feasibility of performing the analysis. In line with Green's (1991) prerequisites, the present study's sample size was appropriate for Linear Regression Analysis. In the first analysis, we adopted career indecision as the outcome variable, and the independent variables were personality (first block), career adaptability and career choice self-efficacy (second block), and career exploration (third block). Next, we performed the second Regression Analysis, also employing the forward method, yet selecting seeking career counseling as the outcome variable while maintaining the same sequence of independent variables in the blocks. We allocated the variables in this manner in their respective blocks aiming at a model that begins with dispositional aspects (first block), then proceeds with self-regulatory processes (second block) and, finally, addresses behavioral aspects (third block), in line with the developmental model proposed by Lent et al. (1994).

\section{Results}

Table 1 displays the mean and standard deviation for the overall sample and for the sample grouped by high school year, in relation to the variables employed in the present study. With respect to the ranges of the means, it is noteworthy that they varied from one to five for all of the variables, except for the factors of self-efficacy and of the seeking career counseling variable, which ranged from one to four and from one to three, respectively.

Table 1

Data of the Sample Grouped According to High School Year and Effect Sizes

\begin{tabular}{|c|c|c|c|c|c|c|c|}
\hline Variables & $M(S D)$ Total & $\begin{array}{c}M(S D) \\
\text { Sophom. }\end{array}$ & $\begin{array}{l}M(S D) \\
\text { Juniors }\end{array}$ & $\begin{array}{l}M(S D) \\
\text { Seniors }\end{array}$ & $d \mathrm{Sp}: \mathrm{Jr}$ & $d \mathrm{Sp}: \mathrm{S}$ & $d \mathrm{Jr}: \mathrm{S}$ \\
\hline Extroversion & $3.05(0.49)$ & $3.08(0.46)$ & $3.02(0.46)$ & $3.04(0.55)$ & 0.13 & 0.08 & 0.04 \\
\hline Socialization & $3.87(0.55)$ & $3.86(0.52)$ & $3.91(0.54)$ & $3.81(0.60)$ & 0.09 & 0.09 & 0.17 \\
\hline Conscientious. & $3.83(0.59)$ & $3.91(0.57)$ & $3.81(0.62)$ & $3.74(0.60)$ & 0.17 & $0.29^{*}$ & 0.11 \\
\hline Neuroticism & $2.71(0.72)$ & $2.71(0.84)$ & $2.67(0.65)$ & $2.77(0.65)$ & 0.05 & 0.08 & 0.15 \\
\hline Openness & $3.16(0.63)$ & $3.17(0.57)$ & $3.20(0.61)$ & $3.12(0.70)$ & 0.05 & 0.08 & 0.12 \\
\hline Concern & $3.76(0.82)$ & $3.73(0.87)$ & $3.76(0.78)$ & $3.79(0.83)$ & 0.04 & 0.07 & 0.04 \\
\hline Control & $3.84(0.81)$ & $3.78(0.84)$ & $3.87(0.85)$ & $3.89(0.75)$ & 0.11 & 0.14 & 0.03 \\
\hline Curiosity & $3.50(0.82)$ & $3.53(0.78)$ & $3.46(0.90)$ & $3.53(0.79)$ & 0.08 & 0.00 & 0.08 \\
\hline Confidence & $3.91(0.79)$ & $3.90(0.79)$ & $3.95(0.75)$ & $3.89(0.83)$ & 0.06 & 0.01 & 0.08 \\
\hline Self-Assessm. & $3.09(0.47)$ & $3.13(0.45)$ & $3.09(0.45)$ & $3.04(0.51)$ & 0.09 & 0.19 & 0.10 \\
\hline Data Collect. & $2.99(0.60)$ & $3.02(0.62)$ & $2.95(0.54)$ & $2.97(0.64)$ & 0.12 & 0.08 & 0.03 \\
\hline Seeking Info. & $2.89(0.59)$ & $2.98(0.56)$ & $2.83(0.56)$ & $2.81(0.65)$ & $0.27^{*}$ & $0.28^{*}$ & 0.03 \\
\hline Planning & $3.20(0.54)$ & $3.20(0.58)$ & $3.23(0.44)$ & $3.15(0.56)$ & 0.06 & 0.09 & 0.16 \\
\hline Environ.Explor. & $3.26(0.80)$ & $3.36(0.84)$ & $3.28(0.76)$ & $3.13(0.78)$ & 0.10 & $0.28^{*}$ & 0.19 \\
\hline Self-Explorat. & $3.48(0.73)$ & $3.58(0.72)$ & $3.51(0.72)$ & $3.34(0.74)$ & 0.10 & $0.33^{*}$ & $0.23^{*}$ \\
\hline Indecision & $2.61(0.66)$ & $2.71(0.65)$ & $2.56(0.65)$ & $2.50(0.67)$ & $0.23^{*}$ & $0.32^{*}$ & 0.09 \\
\hline Seeking CC & $2.01(0.59)$ & $1.98(0.59)$ & $2.09(0.48)$ & $1.97(0.67)$ & $0.20^{*}$ & 0.02 & $0.20^{*}$ \\
\hline
\end{tabular}

Note. Sophomores: $n=93$; juniors: $n=68$; seniors: $n=73 ; M$ : mean; $S D$ : standard deviation; $d$ : effect size; ${ }^{*}$ : small effect size. 
All the mean values' sizes of effects between the three high school years were insignificant or null, indicating in a general manner that none of the three years exhibited prevalence over the other years in terms of the variables' scores. The variables that exhibited insignificant sizes of effects between the years were conscientiousness, seeking practical career information, environmental exploration, self-exploration, career indecision, and seeking career counseling. Table 2 displays the Regression Analysis with the predictor variables in relation to career indecision.

Table 2

Regression between Variables in Relation to Career Indecision

\begin{tabular}{lccc}
\hline Predictor Variables & \multicolumn{3}{c}{ Career Indecision } \\
\cline { 2 - 4 } & $\beta$ & $p$ & $95 \%$ CI $(\beta)$ \\
\hline Neuroticism & 0.21 & $<0.01$ & $0.08 ; 0.30$ \\
Self-Exploration & 0.23 & $<0.01$ & $0.10 ; 0.32$
\end{tabular}

Note. $\mathrm{R}^{2}$ : adjusted coefficient of determination; $\beta$ : adjusted linear regression coefficient; CI: confidence interval. Values of the variables excluded from the model are not given.

Examining Table 2, we determined that, although various variables were included in the analysis with the aim of explaining career indecision, the best explanatory model was made up of the factors neuroticism and selfexploration alone; these two factors explained $9 \%$ of the teenagers' indecisiveness. With respect to the direction of prediction, we observed that both neuroticism and selfexploration positively predict indecision; i.e., the higher the adolescents' level of neuroticism and self-exploration, the more indecisive they consider themselves in relation to their careers. Lastly, aiming at explaining the seeking of career counseling, the results of the Regression Analysis are given below in Table 3.

Table 3

Regression between Variables in Relation to Seeking Career Counseling

\begin{tabular}{lccc}
\hline Predictor Variables & \multicolumn{3}{c}{ Seeking Career Counseling } \\
\cline { 2 - 4 } & $\beta$ & $p$ & $95 \%$ CI $(\beta)$ \\
\hline Neuroticism & 0.22 & $<.01$ & $0.08 ; 0.27$ \\
Self-Assessment & -0.33 & $<.01$ & $-0.59 ;-2.23$ \\
Self-Exploration & 0.17 & .02 & $0.02 ; 0.25$ \\
\end{tabular}

Note. $R^{2}$ : adjusted coefficient of determination; $\beta$ : adjusted linear regression coefficient; CI: confidence interval. Values of the variables excluded from the model are not given.

As in the previous analysis (Table 2), all of the factors for personality, career adaptability, career choice self-efficacy and career exploration were included as independent variables.
Among these variables, only neuroticism, selfassessment and self-exploration were predictors in the best explanatory model, which explained $14 \%$ of the seeking of career counseling. That 
being the case, the factors that positively explained seeking career counseling were neuroticism and self-exploration, the same factors that predicted career indecision. In contrast, the factor that most explained seeking career counseling was self-assessment, negatively predicting the dependent variable.

\section{Discussion}

The present study examined the extent to which personality, career adaptability, selfefficacy and career exploration explain career indecision and the intention to seek career counseling. The results partially confirm the hypotheses that were raised in this study. $\mathrm{H} 1$ predicted that indecision would be explained positively by openness and neuroticism and negatively by conscientiousness and self-efficacy. Nonetheless, the results indicate that neuroticism alone was capable of predicting indecision in this study. Neuroticism refers to an individual's tendency to experience negative emotions, such as sadness and anxiety. Hence, receiving high scores for neuroticism indicates greater emotional instability (John, Naumann, \& Soto, 2008). This fact suggests that teenagers who experience greater emotional instability are more indecisive with respect to their careers than are teenagers who experience less anxiety and depression or who enjoy more positive affects. The literature on the subject further indicates that indecision is positively correlated with anxiety and depression (Hutz \& Bardagi, 2006) and with pessimism (Campos \& Noronha, 2015), traits that are observed in people with high levels of neuroticism. In addition to the above studies, Ourique and Teixeira (2012) also observed that neuroticism negatively predicts university students' career decision making, suggesting that the present study's results are not an effect of age or academic experience.

Besides neuroticism, self-exploration was also a predictor of career indecision, as was hypothesized based on other studies (Ambiel \& Hernández, 2016; Faria et al., 2008). Self-exploration was the variable that best explained career indecision, positively predicting such indeci- siveness. In the present case, the results revealed that the teenagers who pursue self-knowledge the most are those who exhibit greater indecisiveness regarding their careers. This can be explained by the fact that, to the extent that individuals question themselves as to their own interests and values (thus leading to self-knowledge), they can also evoke uncertainties in relation to themselves, thus experiencing difficulties with respect to deciding about their careers.

Also along these lines, $\mathrm{H} 2$ was partially corroborated because it hypothesized that self-exploration and environmental exploration would predict career indecision and the seeking of career counseling. Hence, based on $\mathrm{H} 2$, we also observed that self-exploration was a variable that predicted seeking career guidance. In this case, such results suggest that, aiming at better comprehending themselves students that explore themselves more profoundly exhibit greater intention to seek career counseling services. Such a result confirms theoretical assumptions to the effect that one of the aims of CC work is to encourage greater vocational self-knowledge on the part of those who seek career counseling. It could be for this reason that the adolescents who sought to know themselves better ended up raising doubts regarding themselves, which in turn led to higher levels of indecision within themselves and, consequently, led them to exhibit greater intention to seek CC services, for such services offer them a form of aid in the selfknowledge process (Santos et al., 2014).

A further factor that positively predicted seeking career counseling services was neuroticism, suggesting that the most emotionally unstable adolescents are those who believe they need more of this type of service, probably due to the fact that such teenagers need more help with their lives at that moment and thus consider such services a potential opportunity to get assistance. Studies indicate that individuals with a higher level of neuroticism tend to seek more help for their mental health problems (Parslow \& Jorm, 2000; Zoonen et al., 2015).

Lastly, the factor that best explained seeking career counseling was self-assessment, a negative predictor. With respect to this result, 
one perceives that the adolescents who believe they know themselves well in career terms are those who indicated their lack of intention to seek career counseling. This can be explained by the fact that the more adolescents believe in their aptitude for vocational self-knowledge (Ambiel $\&$ Noronha, 2014), the more deeply rooted their notion that they need no help choosing a career. A further point to be considered is the fact that some adolescents do not recognize their need to seek career counseling due to a level of dysfunctional self-knowledge that is influenced by overconfidence (Moores \& Chang, 2009).

In other studies focused on identifying the complaints made by individuals receiving counseling who were participating in career counseling processes, the following chief complaints were identified: the lack of careerrelated information and research sources (Ribeiro, 2003); the need for larger amounts of vocational and educational information (Bardagi et al., 2003); and uncertainty, indecision and lack of information (Semensato et al., 2009). In the above studies, by way of exploratory and/ or qualitative analyses the authors observed that the chief complaints were associated with variables that were external to the individuals (e.g., lack of information). Nonetheless, such findings diverge from the present study's findings, which reveal that the variables that predict seeking career counseling are internal to the individual (self-exploration, neuroticism and self-assessment). That being the case, one may deduce that when the students in the other studies frankly commented on the motives that led them to seek career counseling, they reported external motives (Bardagi et al., 2003; Ribeiro, 2003; Semensato et al., 2009). In contrast, the adolescents in the present study had less control over the variables because the variables were analyzed using psychometric scales, which enabled us to identify various internal motives for seeking career counseling services.

Lastly, we discerned that the two careerindecision predictors were equally predictive of seeking career counseling, which indicates that these two variables share points in common. The only variable that differentiated the model that explains career indecision from the model that explains seeking career guidance was self-assessment, which was present in the latter model alone. In this respect, the higher the adolescents' levels of neuroticism and self-exploration, the more indecisive they reveal themselves to be, and they end up viewing career counseling as a potential aid for their emotional instability and/ or career indecisiveness. Nonetheless, the adolescents' belief in their ability to know themselves had no impact on their indecisiveness, whereas it did have an impact on their meager intention to seek career counseling.

Based on the present article, it is possible to expand knowledge regarding several variables that contribute to explaining adolescents' career indecisiveness and intention to seek career counseling. Nevertheless, it is still worthwhile to consider some of the present study's limitations, especially concerning the accuracy of personality factors since two such factors (extroversion and openness) exhibited unsatisfactory Cronbach's alphas. In the same manner, studies involving the construction of the Mini-Markers for Personality Assessment have also pointed to similar alphas (Hauck, Machado, et al., 2012; Hauck, Teixeira, et al., 2012), indicating that this is not a characteristic that is specific of the present study's sample. We thus recommend that the present study be replicated in future research, employing other measures of personality so as to more reliably test this variable's influence on the outcome variables tested here.

Another point that deserves closer attention relates to the seeking career counseling variable, which measured the adolescents' intention to seek career guidance regardless of whether or not they actually sought such guidance. That being the case, it is important that future studies check whether the variables that predict the intention to seek career counseling are the same variables that predict the actual act of seeking career counseling services. Furthermore, another hypothesis that needs to be tested relates to whether or not the career counseling process itself is a potential source of indecision since the process seeks to encourage exploration on the part of the individual receiving such counseling. 
While the present study's results are relevant to the comprehension of the constructs, the sample's size and the low regression coefficient we obtained indicate an additional shortcoming of the study. That being the case, there remains a need for future studies that feature data collection at private schools, larger samples, and research that is focused on explaining the same variables that were examined in this study, employing other, previously untested variables, such as sociodemographic and scholastic characteristics.

Indeed, by way of the present study, one can more profoundly comprehend the variables involved in issues that are of vital interest to career counselors, such as adolescents' career indecisiveness and intention to seek career counseling. All things considered, the present study's results indicate that teenagers seek career counseling either because they are feeling emotionally vulnerable or because they are pursuing self-knowledge, or even because they harbor doubts in relation to the level or amount of their career-related self-knowledge. It is thus up to counselors, educators and family members to find ways to minimize or maximize such traits, especially self-efficacy for self-assessment and self-exploration, aiming at collaborating toward wiser career decisions on the part of such teenagers (Silva \& Marques, 2015). Such traits can be encouraged by way of providing the means for adolescents to enjoy access to information concerning their interests, skills, values and needs.

\section{References}

Ambiel, R. A. M., Carvalho, L. F., Martins, G. H., \& Tofoli, L. (2016). Comparing the adaptabilities of Brazilian adolescent students and adult workers. Journal of Vocational Behavior, 94, 20-27. doi: 10.1016/j.jvb.2016.02.005

Ambiel, R. A. M., \& Hernández, D. N. (2016). Relações entre autoeficácia para escolha profissional, exploração e indecisão vocacional. Revista Brasielira de Orientação Profissional, 17(1), 67-75. Retrieved from http://pepsic.bvsalud. org/scielo.php?script $=$ sci_issues \&pid $=1679$ 3390\&lng=pt\&nrm=iso
Ambiel, R. A. M., \& Noronha, A. P. P. (2014). Escala de Autoeficácia para Escolha Profissional (EAE-EP): Manual técnico ( $2^{\text {nd }}$ Ed.). São Paulo, SP: Casa do Psicólogo.

Ambiel, R. A. M., \& Noronha, A. P. P. (2016). Professional choice self-efficacy: Predicting traits and personality profiles in high school students. Psicologia: Reflexão e Crítica, 29. doi: 10.1186/ s41155-016-0021-0

Bandura, A. (1997). Self-efficacy: The exercise of control. New York: Freeman.

Bardagi, M. P., \& Albanaes, P. (2015). Relações entre adaptabilidade de carreira e personalidade: Um estudo com universitários ingressantes brasileiros. Revista PSICOLOGIA: Revista da Associação Portuguesa de Psicologia, 29(1), 35-44. Retrieved from http://www.scielo.mec. pt/pdf/psi/v29n1/v29n1a04.pdf

Bardagi, M. P., Lassance, M. C. P., \& Paradiso, Â. C. (2003). Trajetória acadêmica e satisfação com a escolha profissional de universitários em meio de curso. Revista Brasileira de Orientação Profissional, 4(1/2), 153-166. Retrieved from http:// pepsic.bvsalud.org/pdf/rbop/v4n1-2/v4n1-2a13. pdf

Bonadiman, M. D., Scaff, L. A., Bardagi, M. P., \& Luna, I. N. (2016). Perfil dos usuários do LIOP - Laboratório de Informação e Orientação Profissional da UFSC: Mudanças observadas nos últimos anos. Caminho Aberto, 1(2), 91-100. Retrieved from http://periodicos.ifsc.edu.br/index.php/caminhoaberto/article/view/1880

Borges, L. F. L., \& Andrade, A. L. (2014). Preditores da carreira proteana: Um estudo com universitários. Revista Brasileira de Orientacao Profissional, 15(2), 153-163. Retrieved from http:// pepsic.bvsalud.org/pdf/rbop/v15n2/06.pdf

Brown, S. D., \& Lent, R. W. (2005). Career development and counseling: Putting theory and research to work. Hoboken, NJ: John Wiley \& Sons.

Bueno, J. M. H., Lemos, C. G., \& Tomé, F. A. M. F. (2004). Interesses profissionais de um grupo de estudantes de psicologia e suas relações com inteligência e personalidade. Psicologia em Estudo, 9(2), 271-278. doi: 10.1590/S141373722004000200013

Campos, R. R. F., \& Noronha, A. P. P. (2015). A relação entre indecisão profissional e otimismo disposicional em adolescentes. Temas em 
Psicologia, 24(1), 219-232. doi: 10.9788/ TP2016.1-15

Carvalho, M. M. M. J. (1995). Orientação profissional em grupo: Teoria e técnica. São Paulo, SP: Editorial Psy.

Cohen, J. (1988). Statistical power analysis for the behavioral sciences ( $2^{\text {nd }}$ Ed.). Hillsdale, NJ: Lawrence Earlbaum Associates.

Cunha, M. C. T. C. S. B., \& Faria, L. C. (2009). Efeito da intervenção psicológica vocacional na indecisão e comportamento exploratório. Psicologia Ciência e Profissão, 29(3), 558573. Retrieved from http://www.redalyc.org/ $\mathrm{html} / 2820 / 282021777010 /$

Faria, L. C., Taveira, M. C., \& Saavedra, L. M. (2008). Exploração e decisão de carreira numa transição escolar: Diferenças individuais. Revista Brasileira de Orientação Profissional, 9(2), 17-30. Retrieved from http://pepsic.bvsalud.org/ pdf/rbop/v9n2/v9n2a04.pdf

George, D., \& Mallery, P. (2002). SPSS for Windows step by step: A simple guide and reference. 11.0 update ( $4^{\text {th }}$ Ed.). Boston, MA: Allyn \& Bacon.

Green, S. B. (1991). How many subjects does it take to do a regression analysis? Multivariate Behavioral Research, 26(3), 449-510. doi: 10.1207/ s15327906mbr2603 7

Guan, M., Capezio, A., Restubog, S. L. D., Read, S., Lajom, J. A. L., \& Li, M. (2016). The role of traditionality in the relationships among parental support, career decision-making selfefficacy and career adaptability. Journal of $V o$ cational Behavior, 94, 114-123. doi: 10.1016/j. jvb.2016.02.018

Hauck, N., Filho, Machado, W. D. L., Teixeira, M. A. P., \& Bandeira, D. R. (2012). Evidências de validade de marcadores reduzidos para a avaliação da personalidade no modelo dos Cinco Grandes Fatores. Psicologia: Teoria E Pesquisa, 28(4), 417-423. doi: 10.1590/S010237722012000400007

Hauck, N., Filho, Teixeira, M. A. P., Machado, W. L., \& Bandeira, D. R. (2012). Marcadores reduzidos para a avaliação da personalidade em adolescentes. Psico-USF, 17(2), 253-261. doi: $10.1590 / \mathrm{S} 1413-82712012000200009$

Hutz, C. S., \& Bardagi, M. P. (2006). Indecisão profissional, ansiedade e depressão na adolescência: A influência dos estilos parentais.
Psico-USF, 11(1), 65-73. doi: 10.1590/S141382712006000100008

John, O. P., Naumann, L. P., \& Soto, C. J. (2008). Paradigm shift to the integrative Big-Five trait taxonomy: History, measurement, and conceptual issues. In O. P. John, R. W. Robins, \& L. A. Pervin (Eds.), Handbook of personality: Theory and research (3 ${ }^{\text {rd }}$ Ed., pp. 114-158). New York: Guilford Press.

Joordan, J. P. (1963). Exploratory behavior: The formation of self and occupational concepts. In D. Super, R. Starisshevsky, R. Matlin, \& J. P. Jordaan (Eds.), Career development: Selfconcept theory (pp. 42-78). New York: College Entrance Board.

Kelly, K. R., \& Lee, W.-C. (2002). Mapping the Domain of Career Decision Problems. Journal of Vocational Behavior, 61(2), 302-326. doi: 10.1006/jvbe.2001.1858

Lent, R. W., Brown, S. D., \& Hackett, G. (1994). Toward a Unifying Social Cognitive Theory of Career and Academic Interest, Choice, and Performance. Journal of Vocational Behavior, 45(1), 79-122. doi: 10.1006/jvbe.1994.1027

Magalhães, M. O., Alvarenga, P., \& Teixeira, M. A. P. (2012). Relação entre estilos parentais, instabilidade de metas e indecisão vocacional em adolescentes. Revista Brasileira de Orientação Profissional, 13(1), 15-25. Retrieved from http://pepsic.bvsalud.org/pdf/rbop/v13n1/04.pdf

Melo-Silva, L. L., Lassance, M. C. P., \& Soares, D. H. P. (2004). A Orientação Profissional no contexto da Educação e Trabalho. Revista Brasileira de Orientação Profissional, 5(2), 31-52. Retrieved from http://pepsic.bvsalud.org/pdf/rbop/v5n2/ v5n2a05.pdf

Moores, T. T., \& Chang, J. C. J. (2009). Self-efficacy, overconfidence, and the negative effect on subsequent performance: A field study. Information \& Management, 46(2), 69-76. doi: 10.1016/j. im.2008.11.006

Noronha, A. P. P., \& Ambiel, R. A. M. (2008). Estudo Correlacional entre Escala de Aconselhamento Profissional (EAP) e Self-Directed Search (SDS). Interação em Psicologia, 12(1), 21-33. Retrieved from http://ojs.c3sl.ufpr.br/ojs2/index.php/psicologia/article/view/5998/9208

Noronha, A. P. P., Mansão, C. S. M., \& Nunes, M. F. O. (2012). Interesses Profissionais e Personalidade: Análise correlacional a partir do ATPH 
e BFP. Actualidades em Psicologia, 26(113), 73-86. Retrieved from http://pepsic.bvsalud.org/ pdf/apsi/v26n113/a06.pdf

Organization for Economic Cooperation and Development. (2004). Orientação Escolar e Profissional: Guia para decisores. Lisboa: Gráfica Krispress.

Ourique, L. R., \& Teixeira, M. A. P. (2012). Autoeficácia e personalidade no planejamento de carreira de universitários. Psico-USF, 17(2), 311-321. Retrieved from http://www.lume.ufrgs. br/bitstream/handle/10183/98933/000872886. pdf? sequence $=1$

Parslow, R. A., \& Jorm, A. F. (2000). Who uses mental health services in Australia? An analysis of data from the National Survey of Mental Health and Wellbeing. Australian and New Zealand Journal of Psychiatry, 34(6), 997-1008. doi: 10.1046/j.1440-1614.2000.00839.x

Primi, R., Bighetti, C. A., Munhoz, A. H., Noronha, A. P. P., Polydoro, S. A. J., Nucci, E. P. Di, \& Pellegrini, M. C. K. (2002). Personalidade, interesses e habilidades: Um estudo correlacional da BPR-5, LIP e do 16PF. Avaliação Psicológica, 1(1), 61-72. Retrieved from http://pepsic. bvsalud.org/pdf/avp/v1n1/v1n1a07.pdf

Reis, M., Camacho, I., Ramiro, L., Tomé, G., Gomes, P., Gaspar, T., ...Matos, M. G. (2015). A escola e a transição para a universidade: Idades transicionais e o seu impacto na saúde - notas a partir do estudo HBSC/OMS. Journal of Child and Adolescent Psychology, 6(2), 77-92. Retrieved from https://www.researchgate.net/publication/301354028

Ribeiro, M. A. (2003). Demandas em Orientação Profissional: Um Estudo Exploratório em Escolas Públicas. Revista Brasileira de Orientação Profissional, 4(1-2), 141-151. Retrieved from http://pepsic.bvsalud.org/pdf/ rbop/v4n1-2/v4n1-2a12.pdf

Ribeiro, M. A. (2011). Orientação Profissional: Uma proposta de guia terminológico. In M. A. Ribeiro \& L. L. Melo-Silva (Eds.), Compêndio de Orientação Profissional e de Carreira: Volume 1. Perspectivas históricas e enfoques teóricos clássicos e modernos (pp. 23-66). São Paulo, SP: Vetor.

Ribeiro, M. A., \& Uvaldo, M. da C. C. (2007). Frank Parsons: Trajetória do pioneiro da orientação vocacional, profissional e de carreira. Revista
Brasileira de Orientação Profissional, 8(1), 1931. Retrieved from http://pepsic.bvsalud.org/ pdf/rbop/v8n1/v8n1a03.pdf

Rossier, J. (2015). Career Adaptability and Life Designing. In L. Nota \& J. Rossier (Eds.), Handbook of life design: From practice to theory and from theory to practice (pp. 153-167). Göttingen, Germany: Hogrefe.

Saka, N., Gati, I., \& Kelly, K. R. (2008). Emotional and Personality-Related Aspects of Career-DecisionMaking Difficulties. Campbell \& Cellini, 16(4), 403-424. doi: 10.1177/1069072708318900

Santos, M. M., Luna, I. N., \& Bardagi, M. P. (2014). $\mathrm{O}$ desafio da orientação profissional com adolescentes no contexto da modernidade líquida. $R e-$ vista de Ciências Humanas, 48(2), 263-281. doi: $10.5007 / 2178-4582.2014 \mathrm{v} 48 \mathrm{n} 2 \mathrm{p} 263$

Savickas, M. L. (1999). The Psychology of Interests. In M. L. Savickas \& A. R. Spokane (Eds.), Vocational Interests: Meaning, measurement and counseling use (pp. 19-56). Palo Alto, CA: Davies-Black.

Savickas, M. L. (2005). The theory and practice of career construction. In S. D. Brown \& R. W. Lent (Eds.), Career Development and Counseling: Putting Theory and Research to Work (pp. 42-70). Hoboken, NJ: Wiley.

Semensato, A. C., Valeria, C., Bender, C., Camargo, C., Mata, D., Silva, E. D. O., ...Pessini, M. A. (2009). Um estudo qualitativo sobre orientação vocacional e profissional: Direções possíveis, desafios necessários. Akrópolis, 17(1), 29-40. Retrieved from http://revistas.unipar.br/index. php/akropolis/article/view/2840/2108

Silva, A. D., \& Marques, C. (2015). La exploração vocacional em jovens: Estudo com grupos específicos. Revista de Estudios e Investigación en Psicología y Educación, 2(1), 60-66. doi: 10.17979/reipe.2015.2.1.1085

Silva, C. R. E. (2010). Orientação Profissional, mentoring, coaching e counseling: Algumas singularidades e similaridades em práticas. Revista Brasileira de Orientação Profissional, 11(2), 299-309. Retrieved from http://pepsic.bvsalud. org/pdf/rbop/v11n2/v11n2a14.pdf

Teixeira, M. A. P., Bardagi, M. P., \& Hutz, C. S. (2007). Escalas de exploração vocacional (EEV) para universitários. Psicologia em Estudo, 12(1), 195-202. doi: 10.1590/S141373722007000100023 
Teixeira, M. A. P., Bardagi, M. P., Lassance, M. C. P., Magalhães, M. O., \& Duarte, M. E. (2012). Career Adapt-Abilities Scale — Brazilian Form: Psychometric properties and relationships to personality. Journal of Vocational Behavior, 80(3), 680-685. doi: 10.1016/j.jvb.2012.01.007

Teixeira, M. A. P., \& Dias, A. C. G. (2011). Escalas de exploração vocacional para estudantes de ensino médio. Estudos de Psicologia (Campinas), 28(1), 89-96. Retrieved from http://www.lume.ufrgs. $\mathrm{br} / \mathrm{bitstream} / \mathrm{handle} / 10183 / 98904 / 000787119$. pdf? sequence $=1$

Teixeira, M. A. P., \& Magalhães, M. O. (2001). Escala de indecisão vocacional: Construção de um instrumento para pesquisa. Aletheia, (13), 21-26.

Valentini, F., Teodoro, M. L. M., \& Balbinotti, M. A. A. (2009). Relações entre interesses vocacionais e fatores de personalidade. Revista Brasileira de Orientação Profissional, 10(2), 57-68. Retrieved from http://pepsic.bvsalud.org/pdf/rbop/ v10n2/v10n2a07.pdf

Zoonen, K. V., Kleiboer, A., Beekman, A. T. F., Smit, J. H., Boerema, A. M., \& Cuijpers, P. (2015). Reasons and determinants of helpseeking in people with a subclinical depression. Journal of Affective Disorders, 173, 105-112. doi: 10.1016/j.jad.2014.10.062

Received: $12 / 04 / 2017$

$1^{\text {st }}$ revision: $17 / 11 / 2017$

Accepted: 08/12/2017 